OmniaScience

\title{
Competences acquisition of university students: Do they match job market's needs?
}

\author{
Maria Pujol-Jover ${ }^{1}$, Carme Riera-Prunera ${ }^{2}$, Gemma Abio² \\ ${ }^{1}$ Universitat Oberta de Catalunya (Spain) \\ ${ }^{2}$ Universitat de Barcelona (Spain)
}

mpujoljo@uoc.edu, mcriera-prunera@ub.edu, abio@ub.edu

Received March, 2015

Accepted October, 2015

\section{Abstract}

Purpose: This paper aims at analyzing the skills and competences acquired by students during their university studies, in order to identify the extent to which they fit into society's labor market demands.

Design/methodology/approach: We use data from a survey for firm supervisors corresponding to practices in the Faculty of Economics and Business for the course 2013-14. We analyze the achievement of basic and specific competences and other training project skills, distinguishing by degrees.

Findings: Companies find some lacks in the ability to manage time properly, in being versatile, in the communication skills, the ability to work as a team and specially in having an entrepreneurial view. At the university level, this requires training processes more oriented towards experimentation and problem solving.

Research limitations/implications: The database used refers only to one Faculty of the University of Barcelona. It would be interesting to collect more data and extend the results to a more general context.

Practical implications: It might be interesting both for firms and universities to move closer to one another in a cooperative way. More programs are needed to further 
enhance the employability of graduates and encourage the mobility of teachers in order for them to spend some time performing their research directly at a firm.

Originality/value: This paper explores the immediate and direct relationship established between the university and the labor market through the training period students make during the final stages of their studies.

Keywords: Competences, Abilities, Skills, Internship practices, Firm-university collaboration Jel Codes: A23, J20, M53

\section{Introduction}

It seems that in our society certain disconnections exist when it comes to coordinate business and society needs with what is offered at university. In fact, one of the main problems that we have in higher education is the so-called education paradox: it is difficult to understand how a high rate of youth unemployment can live together with the evidence that organizations cannot find people with the right training. Not to mention the fact that the mismatch between demand and supply is higher when it comes to talk about vocational training. Something does not work. In recent literature there is a growing interest in skills and competencies that students acquire during their university studies, analysing how they fit for the current job market, both at regional (Mora, García-Aracil \& Vila, 2007a, 2007b; Mora \& Félix, 2009) national (Marzo, Pedraja \& Rivera, 2009) and supranational level (Bridgstock, 2009; Nusche, 2008).

A hundred years ago the university was not directly linked to the labour market, first of all because many of the students came from wealthy and influent families and the excellent ones could devote themselves to the academic career. However, when a majority of people managed to become university students a different role for university came into play: it partly targeted at the labour market. That is necessary, since university has to train future workers, but it is also dangerous, since it should focus not exclusively on that.

Since some years ago we face the so-called education paradox: how is it possible that youth unemployment is so high and even so companies do not find people with the right training? Something is not working and we need to find out a solution as soon as possible. At this point the next question to be put is the following: if the market is unable to absorb the graduates, who is to blame? The university? The administration poor planning? The production system? Is it the demand side or the supply side of the economy that fails? How much is the economic model to blame for that? And the education system? Obviously, turning towards a new 
economic and educational model requires a tot of time and changes, which need to be prepared in advance.

One of the current debates in our country between labour market and university is twofold: employers who demand a strict low profile, but trained to manage a firm; and businessmen who complain about the university devoting too much effort to train people with too much general knowledge. At this point we must understand that university is not a vocational school and to do so the debate should be reallocated. This gap between demand and supply of graduates' competences has to be amended as soon as possible. There are different ways to succeed in doing it, for instance, increasing the information and guidance of students in the years previous to university studies, analyse the economy needs in-depth, train students jointly with companies at the end of their studies, etc.

In recent literature there has been a growing interest in the skills and competencies that students acquire during their university studies and how these fit with the current job market (Cajide, Abeal, Barreiro, Zamora, Expósito \& Mosteiro, 2002; Mora et al., 2007a, 2007b; García, 2007; Marzo et al., 2009; Martín, Rabadán \& Hernández, 2013; García-Aracil \& Van der Velden, 2008; Hernández, Martín, Rabadán \& Leguey, 2007; Ugarte \& Naval, 2008; Corominas, Saurina \& Villar, 2010; Guerrero \& De los Ríos, 2012; Alcañiz, Riera \& Clavería, 2013; Harvey, 2000; Heijke, Meng \& Ris, 2003; García \& Mora, 2000; Allen \& Ramaekers, 2006; Biesma, Pavlova, Van Merode \& Groot, 2007; Nusche, 2008; Bridgstock, 2009; Pagani, 2009) to name a few, both at national and European level.

Our work aims at studying further aspects related to the competencies acquisition level of university students and their ability to adapt to the workplace as soon as they get into it in order to see the shortcomings and strengths already developed within their university studies. To do this we explore the immediate and direct relationship established between the university and the labour market, through the training period students make during the final stages of their studies. In particular, we are going to study the point of view of the employees through the assessment of the competences students show and acquire when they carry out the subject "integrated practices" at a firm. The main purpose is to define and clarify the contents of competencies students must finish acquiring once graduated, so that teachers can focus on the implementation of activities in their classes, and assessment practices as well, both intended for improving their level of achievement.

Often a great range of doubts concerning this topic arise to teachers when it comes to dealing with the most relevant skills, how to foster them in class, so that the students end up with a high level of competences, thus easing their access to the labour market. From our first results we will try to identify those actions and activities that can be carried out optimally at the 
university level in order to strengthen them. Nevertheless, we will also try to find out those for which there is still a long way to go in order to adequately focus our efforts, the main purpose being to ensure that students attain the skills they are demanded both from the university and from the labour market. In addition, the conclusions coming from the analysis we undertake may be useful to the academic community when approaching high-standards at teaching level, resulting not only in the acquisition of disciplinary knowledge, but also in a progressive achievement of professional competences throughout the student's university years.

The rest of the paper is organized as follows. Next we set out our case of analysis, then we explain the results and finally we conclude.

\section{Case of Analysis}

In line with the current legislation, which allows the collaborative work between companies and institutions with universities to foster internship agreements for last year university students, the University of Barcelona (UB) offers a course of integrated practices thanks to the agreement for cooperative education between firms and tertiary education institutions.

Internships at UB are a specific training for the students to have a first contact with the labor market. These practices allow them to put into practice what they learn in their classes and also complement their education in a more realistic way. Practices may be mandatory or optional, depending on the Degree they are enrolled in. For undergraduates they will have a maximum of 60 credits, which will be offered at the end of the curricula.

With the aim to bring closer the labor market and the academia, the UB makes available to companies the application "FeinaUB". This service can be accessed electronically by all university students, no matters their Degree (out of 70 degrees offered by the UB). It is also available as a career service for graduates.

For any company or institution to host a student, they just need to register into the application, publish their offer, wait for $\mathrm{CVs}$, select the candidates to interview and choose the student. The manager of the faculty takes care of the whole process. Once the student starts working at the firm he will have two supervisors: the academic, from the university, and the firm supervisor, from the enterprise. When the practices come to an end the firm supervisor will send a report to the academic supervisor explaining the progress of the student's work. 
The collaboration between companies and universities is based on an agreement specifying the students work plan or project training. It details all relevant information concerning duration of internship, schedule, tasks, responsibilities and supervisors' personal information.

Each faculty has its own external academic practices rules. More specifically, the Faculty of Business and Economics regulation was approved by the Academic Committee on the 27th of April, 2012. Afterwards it was approved by the Governing Board on the 8th of May, 2012. This Faculty offers a relative high number of four-year-degrees. Each of them covers 240 ECTS credits divided into Basic Training (BT), compulsory (CO), electives (OT), internships (PR) and final degree paper (FDP). In particular the studies adapted to the European Higher Education Area (EHEA), which are currently offered, are:

- Bachelor of Business Administration (BA)

- Bachelor of International Business (IB) entirely taught in English. The curriculum also includes some specific compulsory subjects, such as Business English, second language for business (to choose between French, Italian, German and Mandarin) and a third optional language for business (to choose between the same above-mentioned languages). In the fourth year of the degree it is highly recommended for students either to attend the International Work Experience (24 ECTS credits) or carry out an international exchange program (with a minimum of 30 ECTS credits coursed in a foreign university).

- Bachelor of Economics (ECO)

- Degree in Sociology (SOC)

- Bachelor of Statistics (STA). It is an inter-university degree (UB-UPC).

The weight of integrated practices can vary between 6 and 24 ECTS credits, which are always part of the elective ECTS credits.

Our analysis is focused on the Faculty of Economics and Business and covers the period from November 2013 to July 2014. As mentioned, each student who enrolls in internship practices has a mentor, who is responsible for the student and shall make a report at the end of the semester, derived mainly from the survey the firm supervisors are committed to fill in at the end of the business practices. We use the data corresponding to last year practices covering the degrees of Business Administration, Economics, Sociology and Statistics, which amounts to 185 students. 
Table 1 below shows the distribution of students among the four degrees, leaded by BA (79\%). This is entirely consistent with the data registration of the faculty, since BA is the degree with the highest number of students enrolled.

\begin{tabular}{|l|r|r|}
\hline \multicolumn{1}{|c|}{ Degree } & Students & Percentage \\
\hline BA & 147 & $79 \%$ \\
\hline ECO & 24 & $13 \%$ \\
\hline STA & 6 & $3 \%$ \\
\hline SOC & 8 & $4 \%$ \\
\hline All together & 185 & $100 \%$ \\
\hline
\end{tabular}

Table 1 . Students enrollment by degree

\begin{tabular}{|l|c|}
\hline \multicolumn{1}{|c|}{ BASIC COMPETENCES } & $\mathbf{0}$ to $\mathbf{1 0}$ \\
\hline $\begin{array}{l}\text { Ethics. Ethical Commitment: critical attitude consistent with ethical and } \\
\text { deontological aspects. }\end{array}$ & \\
\hline $\begin{array}{l}\text { Responsibility. Skills and Learning Responsibility: analysis and synthesis } \\
\text { capacity, global vision, knowledge applied to technical skills. }\end{array}$ & \\
\hline $\begin{array}{l}\text { Teamwork. Teamwork: ability to contribute to a common project and to work in } \\
\text { interdisciplinary and multicultural teams. }\end{array}$ & \\
\hline $\begin{array}{l}\text { Entrepreneurship. Creative and Enterprising Capacity: ability to formulate, } \\
\text { design and manage projects and find new knowledge. }\end{array}$ & \\
\hline $\begin{array}{l}\text { Sustainability. Ability to Assess the Social and Environmental Impact of the } \\
\text { projects, to put into practice integrated and systemic visions. }\end{array}$ & $\mathbf{0}$ to $\mathbf{1 0}$ \\
\hline $\begin{array}{l}\text { Communication Skills. Communicative Ability: ability to understand and } \\
\text { express themselves, both orally and writing in Catalan and Spanish, skills and } \\
\text { abilities in a third language, high achievement of the specialized degree } \\
\text { language and information search ability. }\end{array}$ & \\
\hline Comments & \\
\hline $\begin{array}{l}\text { Decision Taking. Decision-Making Capacity } \\
\text { firm Knowledge. Ability to Analyze Organizations and their Environment: } \\
\text { organizational culture, economic, legal, political and sociological aspects of the } \\
\text { firm. }\end{array}$ & \\
\hline $\begin{array}{l}\text { Act Globally. Ability to Act in a Globalized Environment: ability to assess the } \\
\text { internationalization strategies of the organization and to understand the } \\
\text { implications of the government policy. }\end{array}$ & \\
\hline \begin{tabular}{l} 
Comments \\
\hline
\end{tabular} & \\
\hline
\end{tabular}

Table 2. Survey for firm supervisors. Competences (own elaboration from UB Economics

Faculty Career Service information)

Firm supervisors make an assessment of the student's learning project answering a set of questions divided into three main sections referring to Basic Competences, Specific Competences and other training project skills. To assess the degree of achievement of competences and skills supervisors graded each of them using a 0-10 scale, where 0 implies no competition at all and 10 meant that the competence was reached at the highest level. Regarding the third group, it should also be assessed the degree of completion (full, null or 
partially). In case of partially completion the reasons must be specified in the comments section provided.

\begin{tabular}{|c|c|c|}
\hline Other training project skills & \begin{tabular}{|c|}
$\begin{array}{c}\text { Full / Null / } \\
\text { Partially }\end{array}$ \\
\end{tabular} & 0 to 10 \\
\hline \multicolumn{3}{|l|}{ Being on time. The student was punctual. } \\
\hline \multicolumn{3}{|l|}{$\begin{array}{l}\text { Total working hours completed. The student worked all the practice } \\
\text { hours. }\end{array}$} \\
\hline \multicolumn{3}{|l|}{ On schedule Practices were finished in the internship period. } \\
\hline \multicolumn{3}{|l|}{$\begin{array}{l}\text { Task completion. The student carried out the tasks planned in the training } \\
\text { project. }\end{array}$} \\
\hline \multicolumn{3}{|l|}{ Fitted profile. The student fitted the expected professional profile. } \\
\hline \multicolumn{3}{|l|}{ Motivation. The student has been involved and motivated at work. } \\
\hline \multicolumn{3}{|l|}{ Prone to feedback. The student was receptive to criticism. } \\
\hline \multicolumn{3}{|l|}{ Versatility. The student was versatile. } \\
\hline \multicolumn{3}{|l|}{ Time managing. The student planned and managed time appropriately. } \\
\hline FINAL QUALIFICATION (0 to 10) & & \\
\hline
\end{tabular}

Table 3. Survey for firm supervisors. Skills and final qualification (own elaboration from UB Economics Faculty Career Service information)

The tables above (Tables 2 and 3) summarize the competences and skills to be gained during the integrated practices course, which are the ones the firm supervisors were asked to evaluate.

\section{Results}

\subsection{Basic and specific competences}

With respect to the basic skills achievement we do not observe large differences among the means by degrees. Figure 1 shows a good summary of this situation. The hexagons representing the averages of each competence for each degree analyzed are very similar to each other. In fact, the basic competences averages are almost identical for Responsibility, Entrepreneurship and Sustainability. The average for Responsibility ranges from 8.50 (Sociology) to 8.83 (Economics and Statistics). Statistics students face the lowest value for Entrepreneurship (7.83), whereas Sociology students rank last for Sustainability (8.00).

The most significant differences can be observed when we move to Ethics, Communication Skills and Teamwork. In all cases the lowest value corresponds to Statistics students (green line), and the highest to Economics (red line). The values for Ethics rank from 8.17, to 9.04, a 
0.87 points difference. Regarding Communication Skills the difference jumps to 1.16 between the same two degrees. Finally this gap increases to 1.25 for Teamwork.

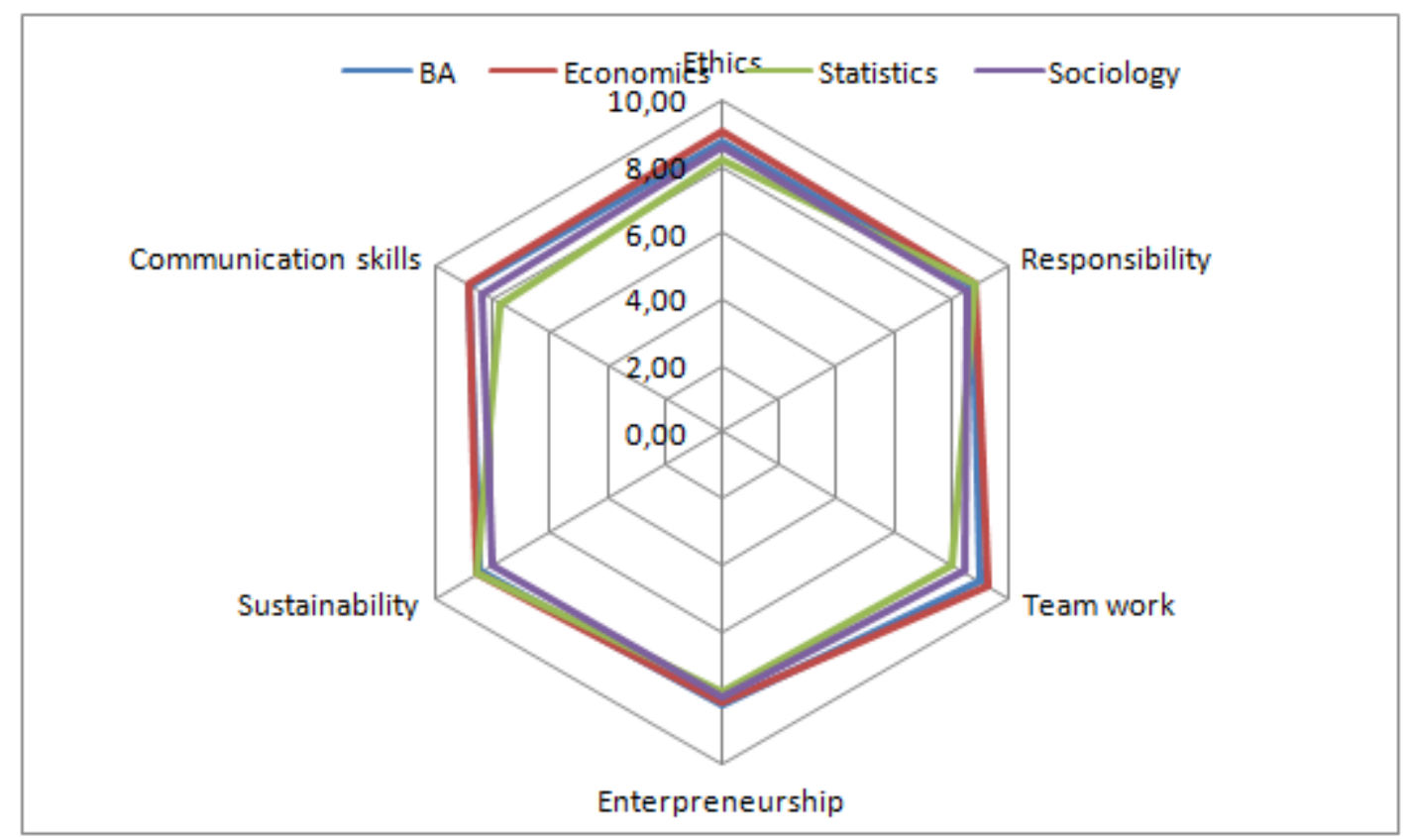

Figure 1. Basic competences averages comparison

When looking at the specific skills something similar occurs (Figure 2 ). In this case, we see that the triangles are almost identical. Decision taking averages are practically the same in the four degrees analyzed. The same holds for Firm knowledge. With respect to that we just want to highlight the fact that the lowest average (7.92) corresponds to Economics. However the means corresponding to Act Globally have a higher variance and they also have a relatively similar behavior to that described above for Communication Skills, Teamwork and Ethics: Statistics students rank last with $9.17,0.58$ points below BA and Economics. 


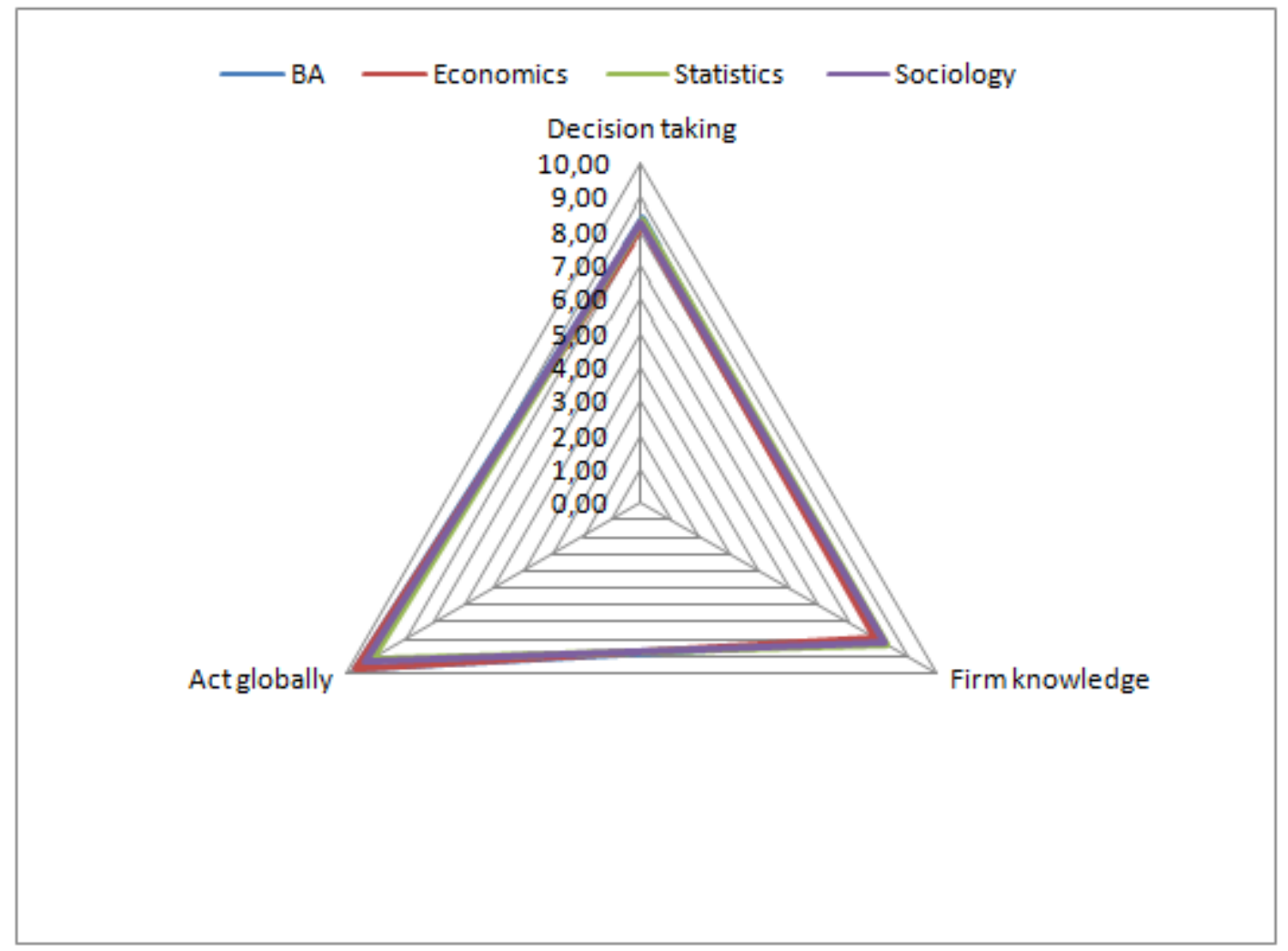

Figure 2. Specific competences averages comparison

Although each item is rated from 0 to 10 we made a scale conversion in order to detect more differences among the obtained ratings and also to ease our analysis. The scale conversion was the following:

- When an item is measured from 0 to 5 we have interpreted that the competence or skill is not achieved and therefore the student is graded with Fail.

- If the rating is 6 or 7 the degree of achievement is low and is graded as Low.

- A rating of 8 means that the competence or skill has been remarkably achieved and can be graded as Medium.

- A rating of 9 implies that the competence or skill was highly accomplished and can be graded as High.

- A rating of 10 means that competence or ability has been fully achieved and can be graded as Complete. 


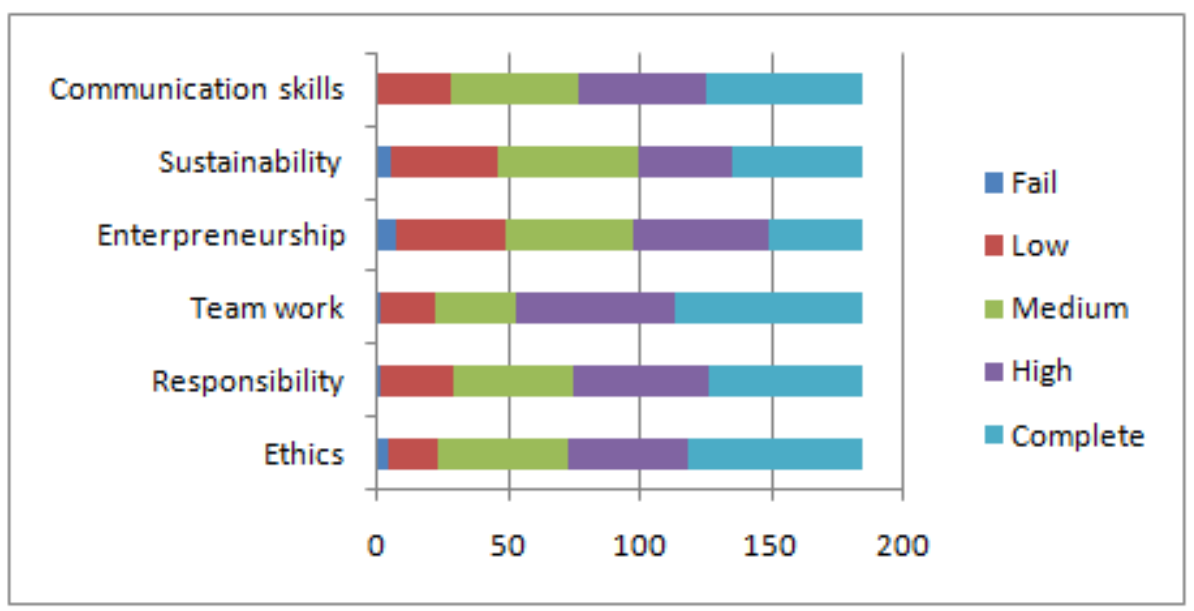

Figure 3. Basic competences frequencies distribution

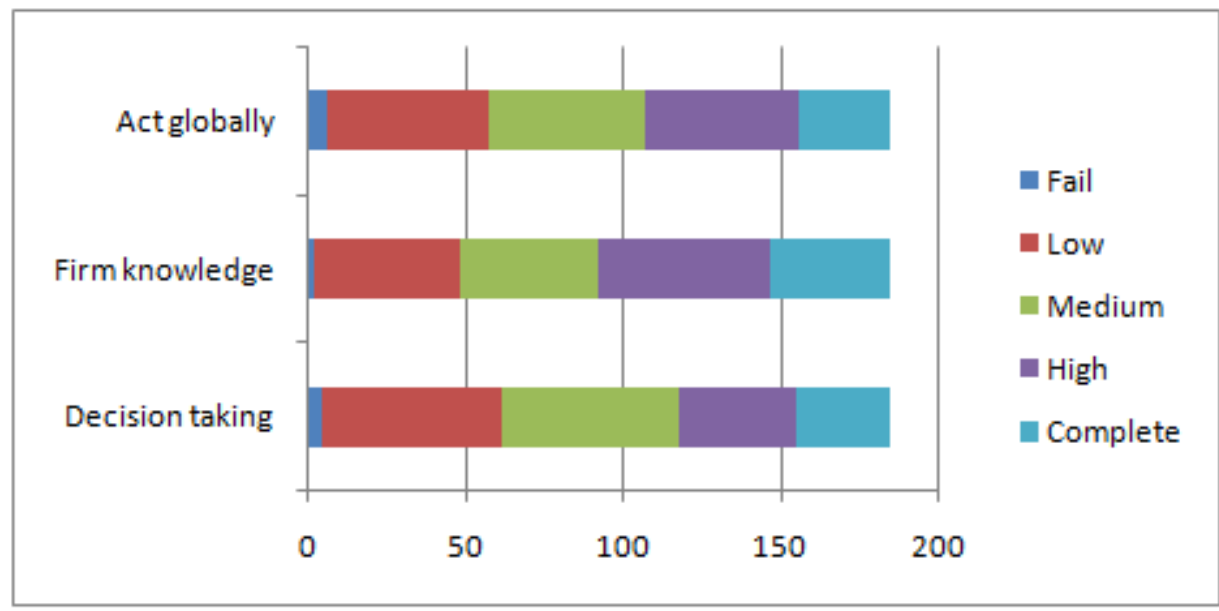

Figure 4. Specific competences frequencies distribution

The frequencies distributions for the basic and specific competences are showed in Figure 3 and Figure 4 respectively. Communication Skills, Teamwork and Responsibility are the core competences that fewer students fail. On the other hand, Teamwork jointly with Ethics are the ones with the highest level of achievement. As a result the global averages for these two competences, no matters which degree we are analyzing, are the highest. Moving to specific competences Firm Knowledge is also in line with the core competence Teamwork, with the largest degree of completely achievement by students and also presenting the lowest number of students who fail. 


\subsection{Other training project skills}

Other aspects to be highlighted are the ones referring to the completion of duties (Figure 5). The assessment coming from the firm supervisors is very good. A very high percentage of students have been always on-Schedule, closely followed by those who had their total working hours completed. Besides, more than two thirds have been on time. At a second level we find completion task, motivation, fitted profile and versatility, with a little bit more than $50 \%$ of students with the highest grade. Finally, the worst rated aspects are time managing and prone to feedback.

According to that we can say that students generally accomplished with the planned tasks, schedule and made the hours specified in the contract. On the other hand, they were quite motivated and versatile but might not know the best way to organize their time and did not handle very well with criticisms and comments coming from their bosses or colleagues.

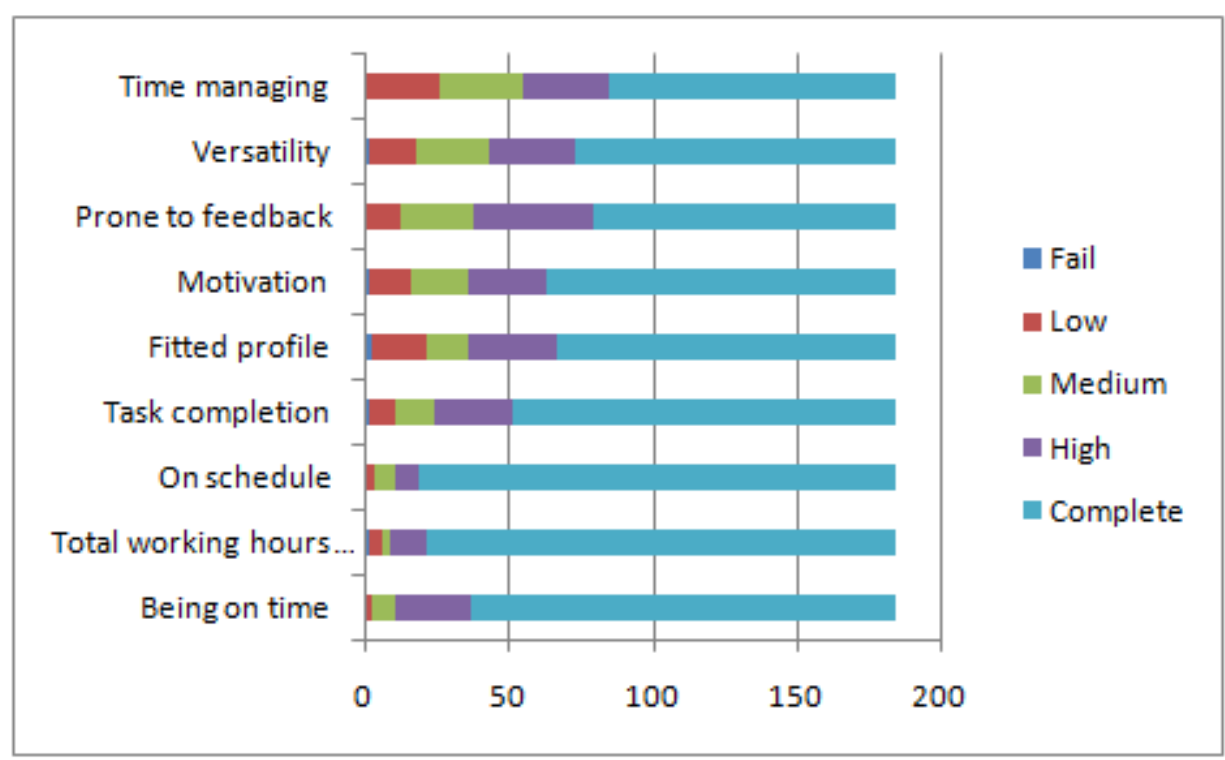

Figure 5. Other training project skills frequencies distribution

\begin{tabular}{|l|r|}
\hline \multicolumn{1}{|c|}{ Degree } & \multicolumn{1}{c|}{$\begin{array}{c}\text { Final } \\
\text { qualification }\end{array}$} \\
\hline BA & 8.92 \\
\hline ECO & 8.79 \\
\hline STA & 8.67 \\
\hline SOC & 9.13 \\
\hline All studies & 8.90 \\
\hline
\end{tabular}

Table 4. Final qualification by degree 
Finally, the global qualification of the integrated practices is 8.90 and it does not differ significantly from one degree to another. The highest value corresponds to Sociology (9.13) and the lowest, to Statistics (8.67). However, since the vast majority of the students come from BA (8.92) it is not easy to appreciate such variability on the overall average qualification (8.90).

\section{Conclusions}

The competences acquisition by students' debate is not new, but it started a long time ago. Lots of researchers have extensively analysed it. In fact, a lot of studies have shown that the level of competences acquired by students is usually below the level required for the job. Nevertheless if the labour market keeps complaining about the poor training of the students finishing their studies, it is obvious there is something that has not been thoroughly analysed or it has not been performed as it should. Therefore we should insist on it. In this line in order to improve the training of our students it might be interesting both for firms and universities to move closer to one another in a cooperative way. So as to do that it may be necessary to modify some aspects of the university governance and encourage the willingness of firms to collaborate. In addition, we would need more programs to further enhance the employability of graduates and encourage the mobility of teachers in order for them to spend some time performing their research directly at a firm. That is to say, we must modernize the university with larger flexibility to respond quickly to the demands of the knowledge society and the international context.

However, the debate based on how to reallocate the education efforts towards the demand side should have a long-term vision. It can only be based on a high demanding one, on an efficient and competitive production model in the long run. Thus we need to promote a cultural change (Brennan, 2008) focused not only on the students but on all the actors involved in the educational process. Students must have a broad vision, provided by professors and driven by the administration, in cooperation with the family, society and especially the business world. This last actor must also improve some aspects, the ability to state their demand, being among them.

Notwithstanding, a certain degree of consensus seems to be reached when it comes to say that we need to promote innovative teachers committed to teaching (Carreras, Martínez, Carrasco, 2006), and a close relationship between university and firms. Moving to the first aspect, to successfully include some changes in the teaching methods, we need to deeply analyse the exact students' needs, lacks and requirements in terms of competences and then promote 
them in a generalized way. With respect to the second one, it should be encouraged the presence of university members in the professional world to adapt their knowledge to reality and ensure that the syllabus includes some of the skills and competences future workers will be required when entering the labour market (Hodges \& Burchell, 2003). Current trends show the growing need for professionals trained to do things, people who can independently solve problems and doing it in an adaptive way. This requires training processes more oriented towards experimentation and problem solving. Our results show the need for motivated people, who act globally, with a vast knowledge of the firm and the market situation. Companies find some lacks in the ability to manage time properly, in being versatile, in the communication skills, the ability to work as a team and specially in having an entrepreneurial view. Those seem to be the main aspects in which our studies need to insist in order to better train our students according to the labour market demands.

\section{References}

ALCAÑIZ, M.; RIERA, C.; CLAVERIA, O. (2013). La formación competencial de los licenciados en Economía y Empresa: una visión desde su entorno profesional. Revista d'Innovació $i$ Recerca en Educació, 6(2): 64-85.

ALLEN, J.; RAMAEKERS, G. (2006). Survey among employers of alumni from the Faculty of Economics and Business Administration of Universiteit Maastricht. Maastricht: Faculty of Economics and Business Administration.

BIESMA, R.G.; PAVLOVA, M.; VAN MERODE, G.G.; GROOT, W. (2007). Using conjoint analysis to estimate employers preferences for key competencies of master level Dutch graduates entering the public health field. Economics of Education Review, 26(3): 375-386. http://dx.doi.org/10.1016/j.econedurev.2006.01.004

BRENNAN, J. (2008). Higher education and social change. Higher Education, 56: 381-393. http://dx.doi.org/10.1007/s10734-008-9126-4

BRIDGSTOCK, R. (2009). The graduate attributes we've overlooked: enhancing graduate employability through career management skills. Higher Education Research \& Development, 28(1): 31-44. http://dx.doi.org/10.1080/07294360802444347

CAJIDE, J.; ABEAL, C.; BARREIRO, F.; ZAMORA, E.; EXPÓSITO, A.; MOSTEIRO, J. (2002). Competencias adquiridas en la universidad y habilidades requeridas por los empresarios. Revista de Investigación Educativa, 20: 449-467.

CARRERAS, J.; MARTÍNEZ, M.; CARRASCO, J. (2006). Propuestas para el cambio docente en la universidad. Barcelona: Octaedro/Universidad de Barcelona. 
COROMINAS, E.; SAURINA, C.; VILLAR, E. (2010). Adecuación de la formación universitaria al mercado de trabajo. Análisis de tres cohortes de graduados en Cataluña. Barcelona: AQU Cataluña.

GARCÍA-ARACIL, A.; VAN DER VELDEN, R. (2008). Competencies for young European higher education graduates: labor market mismatches and their payoffs. Higher Education, 55: 219-239. http://dx.doi.org/10.1007/s10734-006-9050-4

GARCÍA, J.; MORA, J. (2000). El Mercado laboral de los titulados superiores en Europa y en España. Papeles de Economía Española, 86: 111-127.

GARCÍA, L.A. (2007). ¿Qué demandan las empresas de los titulados universitarios? Análisis desde la perspectiva del empresario tinerfeño sobre el proceso de selección de jóvenes titulados universitarios y las características competenciales de éstos. La Laguna: Fundación Empresa.

GUERRERO, D.; DE LOS RÍOS, I. (2012). Professional competences: A classification of international models. Social and Behavioral Sciences, 46: 1290-1296.

http://dx.doi.org/10.1016/j.sbspro.2012.05.290

HARVEY, L. (2000). New realities: The relationship between higher education and employment. Tertiary Education and Management, 6(1): 3-17. http://dx.doi.org/10.1080/13583883.2000.9967007

HEIJKE, H.; MENG, C.; RIS, C. (2003). Fitting to the job: the role of generic and vocational competencies in adjustment and performance. Labour Economics, 10(2): 215-229. http://dx.doi.org/10.1016/S0927-5371(03)00013-7

HERNÁNDEZ, J.; MARTÍN, M.; RABADÁN, A.B.; LEGUEY, S. (2007). Desajustes entre formación universitaria y empleo desde la óptica empresarial: Un análisis cuantitativo y cualitativo. Madrid: Centro Universitario de Estudios Sociales Aplicados.

HODGES, D.; BURCHELL, N. (2003). Business graduate competencies: employers' views on importance and performance. Asia-Pacific Journal of Cooperative Education, 4(2): 16-22.

MARTÍN, M.; RABADÁN, A.B.; HERNÁNDEZ, J. (2013). Desajustes entre formación y empleo en el ámbito de las Enseñanzas Técnicas universitarias: la visión de los empleadores de la Comunidad de Madrid. Revista de Educación, 360(1): 244-267.

MARZO, M.; PEDRAJA, M.; RIVERA, P. (2009). Curricular profile of university graduates versus business demands: Is there a fit or mismatch in Spain?. Education \& Training, 51: 56-69. http://dx.doi.org/10.1108/00400910910931832

MORA, J.; FÉLIX, J. (2009). European Multinational Regimes and Higher Education Policy. En A. Maldonado \& R. Malee Bassett (Ed.), International Organizations and Higher Education Policy: Thinking Globally, Acting Locally? (pp. 192-211). New York: Routledge. 
MORA, J.; GARCÍA-ARACIL, A.; VILA, L. (2007a). Job satisfaction among recent European higher education graduates. Higher Education, 53: 29-59. http://dx.doi.org/10.1007/s10734-0052377-4

MORA, J.; GARCÍA-ARACIL, A.; VILA, L. (2007b). Job satisfaction among recent European graduates: does field of study matter?. Journal of Higher Education, 78: 98-118.

NUSCHE, D. (2008). Assessment of learning outcomes in higher education: A comparative review of selected practices. OECD Education Working Paper, 15. Paris: Organization for Economic Cooperation and Development (OECD). http://dx.doi.org/10.1787/244257272573

PAGANI, R. (2009). Una introducción a Tuning Educational Structures in Europe. La contribución de las universidades al proceso de Bolonia. Bilbao: Publicaciones de la Universidad de Deusto.

UGARTE, C.; NAVAL, C. (2008). Formación en competencias profesionales: Una experiencia docente online-presencial. Estudios sobre Educación, 15: 53-86. 